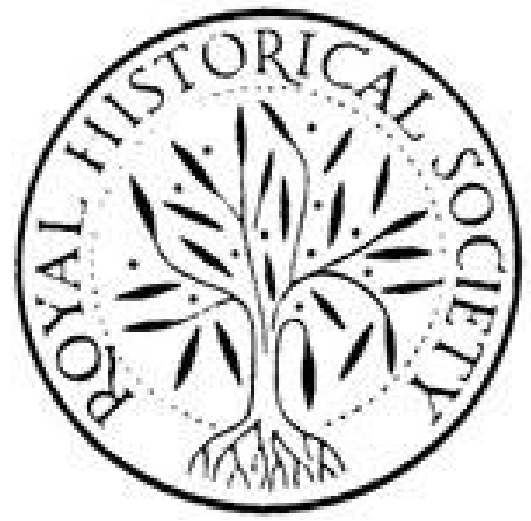

The Case of Lucas and Lisle

Author(s): J. H. Round

Source: Transactions of the Royal Historical Society, New Series, Vol. 8 (1894), pp. 157-180

Published by: Cambridge University Press on behalf of the Royal Historical Society Stable URL: http://www.jstor.org/stable/3678038

Accessed: 26-06-2016 20:15 UTC

Your use of the JSTOR archive indicates your acceptance of the Terms \& Conditions of Use, available at

http://about.jstor.org/terms

JSTOR is a not-for-profit service that helps scholars, researchers, and students discover, use, and build upon a wide range of content in a trusted digital archive. We use information technology and tools to increase productivity and facilitate new forms of scholarship. For more information about JSTOR, please contact support@jstor.org.

Cambridge University Press, Royal Historical Society are collaborating with JSTOR to digitize, preserve and extend access to Transactions of the Royal Historical Society 


\section{THE CASE OF LUCAS AND LISLE}

By J. H. ROUND, M.A.

THERE has been revived in various ways, within the last few years, an old subject of controversy, namely, the execution of Sir Charles Lucas and Sir George Lisle, in cold blood, on the surrender of Colchester to Fairfax in I648. Mr. Firth's discovery of the Clarke papers, his valuable lives of the two knights in the 'Dictionary of National Biography,' Mr. Gardiner's judicial summary of the case, and-magnis componere parva-the erection of a memorial on the scene of the execution by a local enthusiast, have all contributed to remind us of a dispute which has led, at the hands of partisans, to heated and angry recrimination.

Briefly put, the controversy arose from an attempt by the apologists of Lord Fairfax to foist upon us the novel theory that Sir Charles Lucas and Sir George Lisle were not, as was believed, shot in revenge for their gallantry and energy in the defence of Colchester, or, as their epitaph expresses it, 'for their eminent loyalty to their Soveraign,', but that they were shot for a distinct and military offence, under the sentence of a court-martial, before which they were tried, and found guilty, on the specific charge of a breach of parole. Irrespective of the rights of the case, the history of the controversy itself is not a little curious and instructive.

It shows us how, even in these latter days, it is possible to

1 So Lucas's sister, the Duchess of Newcastle, writes that he was 'shot to death for his loyal service.' 
start an historical theory which is not only absolutely without foundation, but at direct variance with all the evidence in the case, and to secure for that theory, by inventing and garbling evidence, unhesitating acceptance at the hands of one of the leading historians of the day.

This theory appears to have been first formulated, though in a somewhat tentative and rudimentary shape, in the 'Fairfax Correspondence' of Mr. Robert Bell.' Mr. Bell wrote as a bitter partisan, and, in his eagerness to clear the memory of Fairfax, he indulged in slanders on Sir Charles Lucas so fanatical in their language as to provoke a smile from any sober historian. ${ }^{2} \mathrm{He}$ also, as is not unfrequently the case, displayed an ignorance of his subject commensurate with the violence of his views. ${ }^{3}$ Yet, disfigured as are his arguments by these two drawbacks, he at least cannot be charged with the infinitely worse offence of demonstrably perverting the truth in order to prove his case. But Mr. Bell's enunciation of the new theory was, as I have observed, tentative and imperfect. $\mathrm{He}$ did not venture to

1 Memorials of the Civil War... forming the concluding volumes of the Fairfax Correspondence. Edited by Robert Bell (1849).

2 'Sir Charles Lucas belınged to that class of bullying, reckless, dare-devil adventurers ... street brawlers and tavern gasconaders... dregs of the English population ... roarers and cut-purses . . . disgraced by crimes and debaucheries. Sir Charles Lucas was distinguished by the unscrupulous passions and audacity of these people . . . rude, bold, and dissolute . . . ready to carry his objects by the most flagitious means . . . set fire to streets and houses, plundered the citizens, and committed other excesses of a revolting kind ' (Fair. fax Correspondence, ii. 36-40).

3 Of this, three instances will suffice. Mr. Bell imagined that the Loyalist general, the Earl of Norwich (Lord Goring), was not one individual, but two. He accordingly described a simultaneous stand by 'Goring at Bow, and the Earl of Norwich at Chelmsford' (ii. 36), thus fairly rivalling Sir Boyle Roche's bird; and similarly enumerated among the prisoners at Colchester, 'Norwich, Capel, Goring,' \&c. ! He also imagined that the famous passage about going 'into Court' in Fairfax's Short Memorial referred to the council of war at the surrender of Colchester, and from this he drew his deductions. It is obvious, of course, as admitted by Mr. Markham, that the passage referred, and could only refer, to the trial of Lord Capel, in the following year, before the High Court of Justice. Thirdly, when quoting Clarendon's opinion (expressed in the language of the period), he actually attributes it (p. 49) to Lord de Grey, who had published, shortly before, his Memoirs of Sir Charles Lucas. 
apply it to Sir George Lisle, and though he pressed it in the case of Lucas, he spoke of the alleged breach of parole, not as the specific ground of his death, but merely as 'another' and additional charge (p. 53).

The argument was taken up afresh at this point by Lord Fairfax's biographer, Mr. Clements Markham, whose wellknown 'Life of the Great Lord Fairfax' (1870) did not appear till more than twenty years after the publication of 'The Fairfax Correspondence.' Six years later, on the occasion of the meeting of the Archæological Institute at Colchester, Mr. Markham read a paper on the famous siege, which was virtually based on the narrative in the 'Life, and in which he vigorously insisted on the acceptance of the new theory. His attack on the memory of the two Loyalist leaders, or, as he was pleased to term it, 'the sullied reputations of mere guard-room soldiers,' ' not unnaturally evoked, as he himself admits, ' a manifestation of such interest and of such strong feeling' ${ }^{2}$ as to lead to a very painful scene, and even, as Mr. Freeman expressed it, to 'personal insults to the chairman.' Mr. Markham, accordingly, at once published an elaborate and final vindication of his case, ${ }^{3}$ on the ground that it was ' an opportune moment to examine the various assertions, and to state the case distinctly and impartially' (sic). ${ }^{4} \mathrm{He}$ also replied to some criticisms on his address by three letters in the local press. 5

Having thus classed together, for facility of reference, Mr. Markham's papers on this historical problem, which he made, it will be seen, peculiarly his own, I proceed briefly to describe his position. He sees, of course, that if Lord Fairfax is to be justified, it is useless to explain away the execution of Lucas by the theory of condemnation for breach of parole, while leaving the execution of Lisle, as Mr. Bell did, unexplained. He therefore applies the theory to the cases of

1 Colchester Address (Arch. Fournal, xxxiv. I19).

2 Fortnightly Review, xxvi. 374 (Sept. 1876).

'Lord Fairfax at Colchester' (Forinightly Review, xxvi. 374).

1 Ibid.

- Essex Standard (Colchester). 
both the knights, though in that of Lisle, neither at the time nor ever afterwards, had a breach of parole been even hinted at. $\mathrm{He}$ also sees, as I shall show in detail, the necessity of formulating more precisely the theory, and of assuming a 'trial' before a 'court-martial' for a specific breach of 'martial law.' By the aid of these deliberate assumptions, which I shall prove in due course to be absolutely baseless, he evolves from his own inner consciousness, as if a matter of historic fact, the statement that, after the triumphal entry into Colchester, Fairfax

returned to his quarters at the Hythe, and a court-martial assembled at the Moot-Hall to try Sir Charles Lucas, Sir George Lisle, Colonel Farre, and the Italian Guasconi ; the two first for having broken their parole of honour, Farre as a deserter, and the foreigner for piracy. Farre managed to escape and Guasconi was pardoned. Lucas and Lisle were found guilty, the facts being notorious and incontestable, and they were condemned to be shot. ${ }^{1}$

The third and last of Fairfax's apologists is no less an authority than Mr. E. A. Freeman, who unhesitatingly espoused the new theory in his own address at Colchester, and who presided over the meeting at which the "very decided views' (as he himself described them) of Mr. Markham evoked, as has been said, 'such strong feeling.'

To Mr. Freeman we may also perhaps ascribe a paper on this subject in the 'Saturday Review,' which appeared immediately after the Colchester meeting, for, from the 'Turk in Bulgaria' to 'the Tor of Glastonbury,' it betrays 'the hand of Esau.' ${ }^{2}$

It was at this point that I took up the controversy myself, and made an exhaustive study of all the contemporary evidence then known. The great bulk of my manuscript stood in the way of its publication, but the latest verdict, I am glad to say, agrees with and fully confirms the conclusions at which I arrived. In the meanwhile, my friend Mr. Firth, to whose marvellous knowledge of the period Professor Gardiner

' 'The Siege of Colchester' (Arch. Fournal, xxxiv. I19).

3 'The Siege of Colchester' (Saturday Revizw, Aug. 12, 1876). 
in his great work has borne striking testimony, had occasion to investigate the question when editing the Life of the Duchess of Newcastle-Lucas's sister-and he set on record in that edition his own conclusions (pp. 95 96, 368-69). He adopted the view that the knights were shot 'by sentence of a court-martial,' and he maintained that, of the 'two reasons for the execution' given by Fairfax in his apologetic despatch, 'the first evidently refers to the breach of parole with which Fairfax charged Lucas' (p. 369). Now this point, I may explain at once, is of essential importance, for in the five words here referred to the upholders of what I call the new theory have found the sole evidence, or rather possibility of evidence, in their favour. This they could only do by misquoting two out of its five words, and thus altering its meaning $;^{1}$ and even Mr. Firth followed suit (p. 96). As he is absolutely incapable of misstating a tittle of evidence, I can only suppose that he followed Mr. Markham, whose work, indeed, he names. Although Mr. Firth has not, I believe, formally retracted this view, he has virtually done so in the adinirable lives he has contributed to the 'Dictionary of National Biography;' where the words of Fairfax's despatch are, of course, accurately quoted. I therefore only allude to the matter because both he and Professor Gardiner refer to his earlier dicta on the subject without any warning against the vital error it contains.

From him I pass to Mr. Gardiner himself, the last volume of whose history, published two years ago, treats this thorny subject with that impartiality and care that we have learnt to expect at his hands. In his note on the passage to which I have referred as misquoted from Fairfax's despatch, he wholly ignores the perverted meaning it had been alleged to convey. 'It will be seen,' he writes, 'that no question was raised of the condemned men having violated their parole; they were shot as traitors to the established authority of Parliament' (iii. 462). This at once disposes of the theory that $\mathrm{Mr}$. justice.'

N.S.-VOL. VIII. 
Markham so stoutly upheld and Mr. Freeman so publicly espoused.

Mr. Firth's Life of Lucas in the 'Dictionary of National Biography' has appeared this year, and in it he tacitly drops the view he had formerly held, and simply follows Mr. Gardiner's verdict. Now it may be urged by both these historians that the newly-discovered Clarke papers have settled the question. I deny that their evidence was needed. The facts as I had worked them out, years before that discovery, were quite sufficient of themselves. But, it may be asked, if the question is settled, what more is there to be said ?

Well, I hold that when a question has formed a subject of acute controversy, it ought to be stated with peculiar clearness and decided so emphatically as to leave no room for doubt. I venture, with all deference, to think that even Mr. Gardiner's solution does not fulfil these conditions.

The space at my disposal is quite insufficient for any detailed investigation of the evidence, but I propose to consider these four points, and to make them as clear as possible :

(I) What was the nature of the execution?

(2) Why did it arouse such peculiar indignation?

(3) On what ground was it justified?

(4) Why were Lucas and Lisle the only prisoners shot?

It will be seen that these points are all questions of fact. When we have settled the questions of fact, we can then on surer ground discuss the merits of the case.

Now, as to the nature of the execution, the evidence is absolutely conclusive. I shall appeal at once to a contemporary tract, which I place next to the testimony of Fairfax himself. Its title runs :

A true and exact relation of the taking of Colchester sent in a letter from an Officer of the Army, who was present at the siege in that service, to a member of the House of Commons. With . . . an account of the cause of giving no quarter to Sir Charles Lucas and Sir George Lisle. 
Nothing could bear more directly on the controversy, and, though written of course from the army standpoint, it is a perfectly frank vindication, and, moreover, strictly contemporary, being published immediately after the execution. It is, therefore, to me astounding that neither Mr. Gardiner nor Mr. Firth should have made use of its evidence. For the present, however, I shall only ask you to bear in mind its title. It blows to pieces the theory of a 'trial' as upheld by Mr. Markham and his friends; the execution was simply a case of ' giving no quarter.'

This conclusion is in exact accordance, not only with Fairfax's despatch, but with the articles of surrender and their appended explanation. Fairfax wrote :-

I have with the advise of a Councell of Warre of the chief Officers both of the Countrie forces \& the Armie caused two of them who were rendred att Mercy to bee shott to Death, before any of them had Quarter assured them. The persons pitched upon for this Example were $\mathrm{S}^{r}$ Charles Lucas \& $\mathrm{S}^{\mathrm{r}}$ George Lisle, in whose Militarie Execuson I hope yo ${ }^{\mathrm{r}}$ Lo: yppe will nott finde cause to think yor Honor $^{r}$ or Justice prejudiced.

As he points out in his 'Short Memorial,' the knights were shot under the clause he had insisted on inserting in the articles of surrender that all superior officers should ' render themselves to the mercy of the Lord Generall,' which mercy, it was fully explained, meant that they' should be 'without certaine assurance of Quarter, so as the Lord Generall may be free to put some immediately to the sword.' We should observe the care with which, in his despatch, he explains that the execution took place 'before any of them had quarter assured them,' implying that his only right to shoot was under this clause, and would cease as soon as quarter was proclaimed.

I have gone thus carefully into the matter, because Mr. Markham, in his desperate attempt to explain away what he terms the 'unlucky note' by Fairfax in his 'Short Memorial,' ventures on the daring assertion that a breach of the terms of surrender ' was the only point that was raised at 
the time, and the only one therefore to which the general in his note ... referred.' ' It is, he wrote, a significant fact that this, and not the justice or 'injustice of the sentences was the issue raised'... 'the friends of the condemned knights thought it safer to raise a false issue than to attempt a discussion of the real point.'

The 'fact' on which such stress is here laid would be indeed 'significant' if only it were true. But what do we find to be really the case on turning to the published 'accusations against the general during his own lifetime,' those made, in Mr. Markham's words, 'by the vile crew that did the carrion work at the Restoration.' ${ }^{2}$ Neither in the protests of the knights themselves, nor in what Mr. Markham terms the 'truculent falsehood upon their gravestone,' ${ }^{3}$ nor in the pages of 'The Loyall Sacrifice'-'spiteful' though Mr. Markham declares it to be-nor in those of the 'True Relation,' nor in those of Clarendon himself, nor even in those of 'Carrion Heath,' is it alleged, or even hinted, that 'the terms of the surrender precluded him from trying any officer of the garrison'! It would, indeed, have been insane to do so, when the articles themselves were so painfully explicit, and when Carter, Fairfax's chief accuser, had scrupulously inserted them in full! Nay, he made a point of reminding his readers that the lives of them all were at the general's mercy.

We then lying at mercy [p. 224] . . . submit they [i.e. the gentlemen] must to the Mercy of an Enemy; and it is a general Rule, That the greatest Token of a generous and noble Soul is never more beautifully shewn than in behaving with good Nature and Civility to an Enemy when subjected to Mercy (p. 225).

Mr. Markham's important 'fact' is therefore most emphatically disproved. He has not only ignored the true character of the charge advanced against Fairfax, but has boldly attempted to substitute a charge of his own devising.

I am obliged to insist upon this point, because Mr. Firth invariably points out that the execution was no breach of the

\footnotetext{
1 Fortnightly Reviea', p. 377. $\quad 2$ Life of Fairfax, p. 328.

3 Fortnightly Review, p. 382.
} 
terms of capitulation. No one can or does pretend that it was.

I now pass to my second point. The charge so loudly brought against Fairfax in the case of Lucas and Lisle was that (not of breaking faith) but of unnecessary (or, in the language of the day, 'barbarous') cruelty in causing them to be shot 'in cold blood.' Of this there is overwhelming proof. 'No wonder,' Mr. Gardiner writes, 'the Royalists lonked on the execution of Lucas and Lisle as an act of brutal ruffianism. Both of them, it was alleged, had fought like soldiers, and had done nothing whilst they were in command to make them unworthy of the treatment usually accorded by soldiers to a brave and high-spirited foe.' As Lord Carlingford well expressed it at the Colchester meeting of the Institute, it was 'one of the very few cruel and unnecessary deeds which disgrace our civil wars.'

Now what, to come to my third point, was the justification alleged by Fairfax and the army? Observe, in the first place, that they admitted such an action required to be justified. Fairfax's despatch is an apology; Fairfax's Memorial is an apology ; the letter from an Officer of the Army is an attempt to excuse the act. We learn from these, the best of sources, everything that could possibly be alleged in defence of the execution. Need I say that no apology, no vindication was needed if, as Mr. Markham pretends, the knights were shot for breach of parole, 'and might justly be put to death by sentence of a court-martial whenever taken in arms.' 1 For that, as he said, ' is a law, which is observed, and which must be observed.' But what do we find? Sundry excuses are offered for the fact, but neither by Fairfax nor by anyone else is advanced that plea of breach of parole which would have made all excuses needless, and at once, ex hypothesi, have justified the act.

In this respect $\mathrm{Mr}$. Gardiner of course follows, as I did, the original authorities. But he selects, as the foremost excuse offered, that a garrison refusing to surrender an

1 Life of Fairfax, p. $33^{\circ}$ 
untenable position had, by the laws of war, forfeited its right to quarter. Often have I read this sentence, and-may I say it with all respect?-wondered what it meant. To judge from Rorke's Drift and from the Residency at Lucknow, the more untenable a position, the greater the glory of holding it. But was Colchester 'untenable' when first summoned? The garrison proved the contrary by holding it through that long and marvellous defence. Had it been relieved, as they fully cxpected, it would never have been taken. Not till Hamilton's defeat destroyed all hope of relief did the position become ' untenable,' and then, so far from refusing to surrender it, the garrison, as Ludlow observes, surrendered at once.

As Edmund Verney truly observed :-

These gentlemen of Colchester tooke up armes by the Prince of Wales hiss Commission, and entered into parley for surrender of the towne assoone ass the Scotts (which were their expected reliefe) were destroyed, and a councell of warr would have condemn'd them had they surrendred sooner.

This point is most important in view of Mr. Markham's persistent assertion that Lucas and Lisle 'had cruelly prolonged the siege with the selfish object of securing their own personal safety.' ' There is no fact more absolutely certain than that every week's additional resistance made Fairfax, as was his wont, more exacting in his terms. His demands rose steadily as the siege continued, and Lisle, at least, might have saved his life had the town surrendered at an earlier date. When we remember how these officers, without a thought for themselves, sacrificed all for the cause they had unselfishly embraced, when we listen to Lucas's dying words, 'I am sure I was firm to that course I undertook,' surely our souls are stirred by the wickedness of such a slander as this -a slander in which its author must have known there was not a word of truth, for within a month of repeating it at Colchester he had publicly admitted of the two knights that

They were gallant soldiers who risked their all without a thought for their own interests. ${ }^{2}$

$$
{ }^{1} \text { Life of Fuirfax, p. 330. } \quad 2 \text { Forinightly, p. } 38 \mathbf{r} .
$$


Mr. Gardiner, in his footnote to his strange sentence, writes as follows :-

Rare instances in which Royalists had acted on this principle were quoted, and Lucas was himself charged with having done so at Canon Froome.

What am I to say? Is it possible that my friend Mr. Gardiner has here-if I may venture on so homely an expression - got hold, for once, of the wrong end of the stick? It is true that at the storm of Canon Froome 'some thirty' of the defenders were 'put to the sword,' though they had 'fled to safety and cried out quarter.' But it was not the wicked Royalists who butchered them. No, it was the Royalists themselves who were thus put to the sword when the place was stormed by Calendar and his Scots (July 22, I645). As for Lucas, how could he be present when, at the time, he was commanding at Berkeley, and anxious about his garrison? I may add that, as to Lucas being cruel to prisoners, 'a contemporary account,' says Mr. Firth, of the capture of Cirencester, ' notices his mercy in taking prisoners.' I commend this passage to Mr. Markham's notice.

But the storm of Canon Froome may serve to illustrate the point which Mr. Gardiner, through some confusion of ideas, has failed to apprehend. The whole sting of the charge against Fairfax lies in the words, 'in cold blood.' They were italicised by Morant a century and a half ago; I italicise them again here to-night. To kill a man 'in the heat of action,' as the phrase ran, is one thing; to butcher him 'in cold blood' is quite another.

'The laws of war'-Mr. Gardiner's phrase-have ever been held to entitle conquerors, in certain extreme cases, and in those alone, to refuse quarter to the conquered. Of these cases the most familiar is that of a storm, the threat of a besieger to give no quarter if compelled to storm being a fair premium on a peaceful surrender ; and the execution of that threat, after a refusal to surrender has made it necessary to storm, being perhaps justified by the loss thus involved on 
the besiegers. Even then it is an act of vengeance which is deemed exceptionally harsh, and is only justifiable, as at the storm of Drogheda, as a means of inducing the remaining garrisons to submit without similarly compelling a storm. Of this there were some notorious examples about this very time in Ireland, and Ludlow mentions, in justification, that at Kilkenny

the garrison, being admonished by the examples made of their friends at Tredagh and Wexford, thought fit to surrender the town timely. ${ }^{1}$

But the warfare in England had hitherto been conducted on more humane principles than in Ireland, as being a contest between men of the same race and creed, not as a guerre $\dot{a}$ outrance. Yet even under circumstances of the most bitter hostility the plea of 'the laws of war' could not have been raised at Colchester. Mr. Markham himself ingenuously admits that the question here arises, what offence ' had been committed for which military justice demanded satisfaction ?' 2 Not only had Fairfax obtained the town without being compelled to storm (or, as he himself expresses it, ' without further bloodshed'), but even if the garrison had compelled him to storm, he had not the plea that their punishment would serve to deter others, for he knew that, with the fall of Colchester, the struggle was virtually at an end.

The charge, therefore, against Fairfax was that he had neither put the knights to the sword in the maddened carnage of a storm, nor allowed them to be tried and executed as traitors to the State, but had butchered them in cold blood after a peaceful surrender. That he bargained beforehand, in the articles, for the privilege of doing so obviously does not lessen the savage cruelty of the deed.

Edmund Verney's comments are here so apposite that they must be quoted in extenso:-

It wass a high tyranny to bring thiss extreame into his power, for ass every gentleman and souldyer iss obliged to a punctuall obser-

$$
1 \text { Memoirs, i. } 306 .
$$

2 Fortrightly, p. 377. 
vance of the trust committed to him by defending to hiss utmost all persons, townes, and forts under his command, soe there iss a civill and honourable custome, and soe authenticke that it may not impropperly be called a lawe amongst souldyers, to give noble and honourable conditions to theire enemy though in the greatest straight and necessity.

The 'examples' he gives of such noble conduct 'when the besieged could not hold out an houre' are those of the Prince of Orange, who at Bois-le-Duc, even after he had begun his storm, 'gave the besieged their own conditions' on their asking for terms, ' and thiss after sixe or eight months' siege,' and of Lord Calendar, who, when the Governor of Hartlepool's soldiers 'conspired to deliver him up,' promptly, 'abhorring this treachery, sent in their base engagement to the Governor by a trumpet of his own, and withall hiss name to a blanke sheete of paper, and desired him to write his own conditions.' Fairfax displayed no such nobility towards his gallant but helpless foes, ${ }^{1}$ nor did this 'true and spotless knight' ${ }^{2}$ feel such abhorrence for treachery as did the rugged Scot. Indeed, on more than one occasion he seems to have offered terms to the soldiers if they would desert their officers, and had to be sternly reminded in consequence 'that it was not Honourable or agreeable to the usage of war' to do so.

A striking contrast to his merciless demand is afforded by the action of the Duke of Newcastle, who, we are told by his wife ${ }^{3}$ (Lucas's sister), summoned Howley House to surrender, but in vain, and had to storm it (1643). Only 'some few' of the garrison were killed, the rest being made prisoners, including the governor. The Duke would have refused him quarter in the storm, but when it was over gave him his life, 'saying it was inhuman to kill any man in cold blood.' And yet he was exasperated by having to storm, which Fairfax was not. Such is the point that, I venture to think, Mr. Gardiner has failed to bring out.

1 - Ever generous to a defeated foe, Fairfax did not confine his kind offices to the concession of exceptionally honourable terms on the field' [!] (Life, p. 401 )
2 Ibit.
8 Ed. Firth, p. 45. 
This, then, is why Sir Charles Lucas, as we read in Rushworth and Whitelocke, 'urged it much that the way taken with him was without precedent,' and this is why in his dying speech he recurred to the same point:

Was it ever knowne that a man did suffer in this kind in cold blood by such an order as this? ${ }^{1}$

This is why it was even admitted by the 'Officer of the Army' that this was 'the first example of Justice' (sic)-mark that word-' that ever was shewed in this kinde' ${ }^{2}$ why Edmund Verney wrote (September I4) that 'Fayrefax's own party doe soe exclayme against the butchery ... that it's thought there is an end of proceedings of that kind'; why Clarendon makes it his gravamen that

the manner of taking the lives of these worthy men was new and without example, and concluded by most men to be very barbarous;

why Edmund Verney again complains :

We heare their own party cry down thiss act ass so Horrid and barbarous that it is beleev'd they will proceede no further in this bloudy manner ;

why Carter complains, with indignant grief: 'This was a new, unheard-of way of condemning men in our nation.' Englishmen, then as now, were devoted to fair play, and that men should be butchered without trial, not in the heat and carnage of a storm, but after a peaceful surrender, and in cold blood, that, in short, in the words of the famous epitaph, they should be 'in cold blood barbarously murdered,' was, in Heath's words, 'most highly resented,' and struck the nation with horror as 'a new and terrible thing.' 3

1 The Loyal Sacrifice.

2 'This is the first example of Justice that ever was shewed in this kind (since [i.e. during] the first and second war) by the Parliaments party, though it be according to the rule of war (in submitting to mercy)'; an argument which does not profess to justify its cruelty.

3 Thus it was that the terrified Italians described the practice of the French, in the invasion under Charles VIII., to give no quarter in battle : 'Et jamais nul ne fait prisonnier, ce que par adventure jamais n'advint en bataille ... Leurs batailles d'Italie n'ont foint acc ustoumé d'estre telles' (Mémoires de Commines, viii. 6). See also, on this point, Guicciardini. 
We see that even the plea of a storm cannot here be advanced. Nor was it. The victors had to fall back, in vindication, on the gallantry, or, as they termed it, the obstinacy, of the defence. Carter and Clarendon give the same version of the Council of War's decision-namely,

That after so long and so obstinate a defence it was highly necessary, for the example of others, that some Military Justice [observe those words, 'some Military Justice'] should be executed, and therefore that Council had determined they three should be presently shot to death.

Now I ask no one to take this on the uncorroborated evidence of Carter and Clarendon; I ask them to compare it with the words of Fairfax. He employs in his despatch the same phrase, 'some satisfaction to Military Justice'; and he similarly speaks of the two knights as having been ' pitched upon for this example.' Further, when we turn to his 'Short Memorial,' we find him insisting, like the council, on the length and obstinacy of the defence, and worse still, I am sorry to say, grossly exaggerating both in order to eke out his case. Truly that passage, in Mr. Markham's words, is for him an ' unlucky note.'

So again, the 'Officer of the Army' tells us that examples of Justice were done upon Sir Charles Lucas and Sir George Lyle ; the former was conceived (and too true) to be the cause of the ruine of this place, his interest in the Town drawing the army thither. He was the head of all those that did rise in this country.

Bitter as was the writer against the loyalist officers, he did not venture to lay to their charge the least ' stain on their military honour ;' their defence of Colchester was the only crime their enemies laid to their charge.

My fourth and last point is of great importance. Why were Lucas, Lisle, and Gascoyne 'pitched upon,' to quote Fairfax, for 'military execution'? Well, I am tempted first to read to you the delightfully confident explanation, given by Mr. Markham's staunch ally at the Colchester meeting:-

Unless Fairfax and his court-martial are to be set down as a strange mixture of knaves and fools, they must have had some special 
reason for picking out these two, and these two only, to suffer the utmost rigour of the terms of surrender . . . and the fact that the two knights had given their parole, while the two peers had not, is the only difference which can be seen between the two cases.

Such is history 'as she is written' by-Mr. Freeman. Unfortunately for him and Mr. Markham, Fairfax himself had carefully explained that 'the only difference ... between the two cases' was (not the distinction of which Mr. Freeman was so confident but) the difference of social status! In his 'Short Memorial ' he asserted that he had declined to execute the Peers,

being considerable for Estates and Familys; but Sir Charles Lucas and Sir George Lisle, ${ }^{1}$ being mere Souldiers of Fortune, and fallinge into our Hand by chance of Warr, Execution was done on them: And (in this Distribution of Justice) I did nothinge but accordinge to my comission and the Trust reposed in mee.

Since I wrote my monograph, the Clarke papers have been discovered, and, as quoted by $\mathrm{Mr}$. Gardiner, they confirm with startling force my own contention. Fairfax, we read,

urged that it would be more fitting to leave peers to be proceeded upon by the power of civil justice, and that the other persons being more near to the condition of soldiers of fortune, and less eminent, should be set apart for the military execution.

Mr. Gardiner does not refer to the passage in the "Short Memorial,' but you see that the two confirm each other with marvellous exactness.

There rise to our ears the words of Ludlow describing his similar predicament, after the surrender of Gourtenshegore :-

I called a Council of War ; and being pressed by the Officers that some of the Principal might be punished with Death for their obstinacy, I consented to their demand. ${ }^{2}$

1 Observe that here again Fairfax confines himself to those who were actually put to death.

${ }^{2}$ Memoirs, i. 354. Ludlow, though famous for having deliberately smoked a body of Irish to death in a cavern (Ib. pp. 422-24), had been moved by the cries of this garrison, as he was burning them out:-- they hung out a white flag 
The parallel must, in truth, have been a striking one. Fairfax had similarly 'called a Council of War,' and 'being pressed by the officers,' headed by Ireton,' 'that some of the Principal might be punished with Death for their obstinacy' - mark the recurrence of that very word-saw the danger of consenting to that demand, saw also the danger of refusing it, and decided to do neither the one nor the other, but to take refuge in an ingenious compromise, or, as he terms it, ' distribution of Justice.' ${ }^{2}$ The three Peers, said this military Solomon, 'being considerable for Estates and Familys,' must be handed over to 'the Civil Judicature,' and to the tender Mercies of 'Civil Justice,' but 'for some satisfaction to Military Justice,' he consented to the demand for 'Military Execution ${ }^{\prime}{ }^{3}$ in the case of the three commoners.

The saints, like hounds, had to be blooded, and Fairfax felt that he could not throw them less than a couple of knights. For this purpose he 'pitched upon,' as he expresses it, Lucas and Lisle, as the leading defenders of Colchester after the peers.

This so-called 'Distribution of Justice' explains and confirms Lord Capel's protest,

that as they were equally concerned, and acted alike in the Engagement and Management of the whole Affair, they should [that is, they ought to] have shared one Fate (Carter).

b gging earnestly for mercy and that we would take away the fire' (Ib. pp. 353354).

1 That Ireton was foremost, throughout, in the demand for 'Justice' on the Loyalists is virtually beyond question. Mr. Markham treats with scorn 'Claren. don's suggestion that the Colchester executions were due to the influence of Ireton' (Life, p. 360) ; but how strong and widespread was this belief at the time is strikingly evidenced by Evelyn's version that Lucas and Lisle were ' murdered by Ireton (sic) in cold blood' (Diary, July 8, I656).

2 This important expression is wholly omitted from that 'garbled version' which Mr. Markham quotes.

3 Fairfax's Despatch (Rushworth, p. 1243). I have called attention, by the insertion of a ' $(s i c)$,' to the peculiar use of the term 'Just ce' which at this time prevailed. In the mouth of the Army it was, as I have shown, the synonym of 'punishment' or 'vengeance.' Steel, in his argument against the Duke of Hamilton (when on his trial with Capel, \&c.), d stinguishes between 'military' and 'civil justice': 'No security from the stroke of civil justice belongs to the prisoner by this refuge ; for as to the milit..ry', that is not the contention.' 
We have it, then, here actually established that, at the time of the execution of the two knights, it was neither alleged by their enemies nor suspected by their friends that they had committed any breach of martial law, which could separate their cases from those of their brother leaders. Now Mr. Markham has ultroneously recorded his opinion that the execution of Lord Capel was 'a judicial murder.' ' But it was clearly, as we have seen, recognised by Fairfax, and also admitted by Capel himself, that the slaughtered knights and he were in precisely the same position. Consequently, if the execution of Lord Capel - who had the advantage of a solemn and formal trial, and whose sentence, pronounced by the High Court of Justice, was discussed and ratified in Parliament-was indeed, 'a judicial murder,' it follows that the execution of Lucas and Lisle-who were 'put immediately to the sword,' for the same offence, without trial, and in cold blood-was emphatically 'a barbarous murder.' Thus the statement, in the inscription on their tombstone, that they were 'IN COLD BLOOD BARBAROUSLY MURDERED,' though declared by Mr. Markham to be 'a truculent falsehood,' ${ }^{2}$ is, on his own showing, irrefragably true $!^{3}$

The other testimony I call to the truth of the famous epitaph is that of Mr. Freeman himself, who rashly admitted

1 ' His execution was cruel and unnecessary, and, in my opinion, that majority was guilty of judicial murder' (Arch. Fourn. xxxiv. 119).

2 Fortnightly, p. 382.

3 The expression 'barbarously murdered' was in frequent use at the time. It was applied, for instance, to the execution of Lord Capel, both in his epitaph and his widow's petition to the Crown ; and to that of Charles I. in Walker's Historical Discourses, \&c. It would be, obriously, even more applicable in such a case as that of Lucas and Lisle. The Loyalist narrative of the siege of Colchester, found among the Duke of Beaufort's MSS., speaks of Lucas having 'now received the reward of his Christian charitie, whilst his barbarous murderers are persecuted with their own guilt.'

Lucas's sister, the Duchess of Newcastle, describes the knight as ' inhumanly murdered and shot to death.' Mr. Firth takes exception to the term ' murdered.' But if he will refer to the preamble of the Act for constituting the High Court of Justice a few months later, he will find that those who had fallen in the Civil War are formally described as ' murdered,' while the sentence on Charles I. describes him as a 'murderer' (iii. 581, 582). The term, therefore, was correct at the time. 
that if the peers ' had been shot . . . it might have been in itself a barbarous murder.' But as Fairfax assures us that the distinction in their treatment was due not to any difference in their offence, but merely to the difference in their social status, it follows that if, by Mr. Freeman's admission, the shooting of the peers might have been 'a barbarous murder,' the shooting of the knights for no different offence may similarly be regarded as 'a barbarous murder.'

I have endeavoured to establish as briefly as possible these points :

First, that there was no court-martial, no 'trial,' no 'finding,' but simply a putting to the sword in accordance with the articles of surrender.

Second, that the charge brought against Fairfax was that of barbarous cruelty in shooting defenceless men in cold blood.

Third, that the only vindication offered by himself and his friends was the activity of their victims and the prolonged gallantry of the defence.

Fourth, that Lucas, Lisle, and Gascoyne were eventually 'pitched upon' for execution because Fairfax hesitated to put peers to the sword, and these knights were the chief leaders after the peers. I should add that Fairfax was thoroughly consistent in selecting leaders as such for the extreme penalty, having proclaimed, at the very outset of the campaign, in his Blackheath manifesto (May 30) that 'Justice' would be done on 'such only as shall appear to have been the chief and most eminent actors and fomenters thereof, and that chiefly for example to others and necessary reparations for the Damages,' \&c., \&c.

So much for the matters of fact. Questions of opinion would lead us into a far wider field, but there are one or two points upon which we may arrive at an agreement. It has always been held, since the days of Clarendon, that Ireton was largely responsible for this cruel act of vengeance. $\mathrm{Mr}$. Markham, however, the champion of Fairfax, hotly rejects 35 * 
the suggestion (p. 360), maintaining that 'Lord Fairfax is well able to bear the responsibility of his own acts, nor would he suffer anyone to induce him to act otherwise than as his conscience prompted.' But this view cannot stand.

Fairfax, as we know, eventually insisted on the whole of the officers 'surrendering to mercy.' It is at first sight difficult to understand why he should have insisted on such extensive powers if it was his intention only to select a mere handful for actual 'exception.' In the companion siege-that of Pembroke-Cromwell stipulated by name for the 'exception ' of those he had made 'election of' for punishment. Why did not Fairfax do the same? The irresistible inference to be drawn from the contrast is that the general and his council had been unable to agree as to whom, or how many, they should make ' election of.' Consequently, their decision on that point was deferred till after the surrender. Carter explains the rigour of the terms as due to the fact that

Fairfax (at the instigation of his Council of War) was fallen from these conditions which formerly he had offered.

We may fairly give Fairfax the benefit of the doubt, and believe that, as Carter here asserts, his hand was really being forced by the violent faction in his council. In that case, he may have decided to pacify them for the time by reserving to himself the power of wholesale butchery, ${ }^{1}$ while for his own part intending, as indeed he himself assures us, 'chiefly, and for the Generality of those under that Condition, to surrender them to the Mercy of the Parliament in General.' ${ }^{2}$

The existence of this extreme or Cromwellian faction among the officers of the besieging army is a most important fact. Fairfax, though nominally general, found himself in a falser position than ever, the inevitable result of his perverse obstinacy and wilful blindness to the signs of the times. ${ }^{3}$

\footnotetext{
1 'So as the Lord General may be free to put some immediately to the sword' (Rushworth, p. 1247).

2 Ibit. This phrase is believed to be corrupt.

${ }^{3}$ Hallam observes of him, with good-natured contempt, that in Charles I. he 'had for once found a man less discerning of the times than himself.'
} 
While the Army Party used him as a moderate and aristocratic figure-head, every one of his chief officers-practically the whole of his council of war-was unquestionably committed to views and to schemes of which he professed the utmost abhorrence. No wonder we find him bitterly complaining that

the arbitrary and unlimited Power of this new Councell would act without a Generall, and all that I could doe, could not preuaile against this streame. . . I must needs say, from the time they declared their Usurped Authority at Triplow Heath, I neuer gave my free Consent to any Thinge they did. ... A And into such Failings all Authoritys may fall. . . . Soe here hath a General's Power bene broke. ${ }^{1}$

The fact of this dissension between the general and his council was an open secret at the time. Ludlow has recorded for us that he went down to the leaguer on purpose to impress upon Fairfax the necessity of decisive measures, and that, mistrusting his resolution, he had recourse to Ireton, as the recognised head of that faction in the camp which represented the now dominant 'Army Party.'

I have my own idea as to the objects of this extreme faction in urging upon Fairfax that deed of blood. But apart from intrigue we have to do with men who, like a heathen priesthood, had tortured themselves into the stern belief that the blood of their fellow saints was calling to Heaven for vengeance, and that they themselves were guilty in the sight of God till they had avenged it on their enemies. Only so, in their own phrase, could they 'be at peace with God.' This was Hebraism run mad. It was well reproved in the words of that worthy chaplain, Sprigge :-

Indeed the state of Israel fought by such laws against the nations, as in the case of Agag; but how far such laws are rules to the state of Christians, who are not under that judicial policy and special precepts, I leave to be disputed . . . surely justice is not all of one colour, all purple ; there is punishment by banishment and confiscation as well as death. 
One is reminded of David Leslie's words, when one of these mad fanatics had insisted on his slaying the Amalekites, in other words butchering his prisoners in cold blood. 'Now, Mr. John,' said the warrior to the reverend man of God, ' have you not once gotten your fill of blood?'

In the loud cry for 'military Justice,' I also see, though Mr. Gardiner does not, the fear of the army that the Parliament's justice would be all too mild and gentle. That apprehension proved correct, when the House decided as to the three peers that they need only be banished (November I8, 1648).

Lastly, let us briefly glance at the conduct of Fairfax himself. Instantly, two pictures rise vividly before us, two famous historic scenes standing out from the darkness in lurid light. In the one, Fairfax, the merciless conqueror, is sending to their death, in cold blood, men whose only offence it was that they had striven to set free their captive king. In the other, Fairfax, on the side of the king, when now, in its turn, the winning side, foremost in restoring the Stuart to his throne, and thereby securing his own safety by 'a full pardon under the Great Seal.' '

In the one, the iil-fated Lucas and Lisle, in the spirit of Christian gentlemen, are meeting death, in Whitelocke's words, 'with very much courage.' In the other, Fairfax, having performed himself what he shot them for attempting to perform, presents in his adulation the restored monarch with a steed, which he effusively exhorts to please his 'royal rider.' But he who, when he shot the gallant knights, desired that God might 'have the glory of his multiplyed mercies,' has now dropped the cant, and has taken to doggerel. Those unlucky verses are a sad trial to his friends. Only a folly of his 'old age,' pleads his champion, Mr. Bell. His age was forty-eight.

There they are, those two pictures, by no human ingenuity to be evaded or blotted out. What are the reflections they suggest ?

Life of Fairfax, p. 384. 
Firstly, that Lucas and Lisle were defending the existing constitution-a monarchy. They were fighting, at least, for monarchy and a king, in a land which was still a monarchy and which had a crowned king. Fairfax, when he rose ' with a view to the Restoration' (p. 375) was attempting to overthrow the existing constitution-a commonwealth-to which, further, he had pledged his fidelity. ' $\mathrm{He}$ restored the Monarchy,' Mr. Markham admits (p. 385), to a land which was then 'a Republic,' and had no crowned king. If theirs was an 'insurrection' so was his, but, constitutionally, of a far more flagrant character.

What is treason? What is insurrection? We all know the epigram as to successful treason, and with equal truth we may apply it to insurrection. Had Fairfax been unsuccessful, his would have been an 'insurrection,' and, conversely, if the Loyalists had won, as they ought to have done ("The danger was extreme,' Mr Markham admits ; their opponents were in dread of 'imminent ruin,' Mr. Firth has lately reminded us), then Lucas and Lisle would not have been 'insurgents,' nor as 'ringleaders of the insurrection' proceeded against as ' traitors.'

Well may Mr. Gardiner speak of the 'elastic charge of treason.' Lucas was not a traitor to him 'who, in the eye of the law,' Mr. Gardiner admits, 'was still his sovereign' (p. 292); 'I am no traitor,' he proudly retorted, when his foes took refuge in that charge, 'but a true subject to my king and the laws of this kingdom.' ${ }^{2} \mathrm{He}$ was not even a traitor to

1 Mr. Markham, indeed, writes : ' Lord Fairfax accepted a seat in the Council of State; but he firmly refused to sign a declaration which was presented to the Councillors on taking office, by which they would have been made to express approbation of the abolition of kingship and of the House of Lords' (Life, $\mathrm{p}$ 354). It will probably be sufficient to quote the Resolution of the House of Commons, $20 \mathrm{Feb}$. 1649-50, reciting that Fairfax had 'taken and subscribed the Engagement appointed for the Members of the Council of State, viz.' :-

'I do testify that I do adhere to . . . the settling of the Government of this Nation for the future, in the way of a Republic, without King or House of Peers : And I do promise, in the sight of God, that through his Grace, I will be faithful in performance of the trust committed to me as aforesaid ' (Commons Fcurnals, vol. vi.).

2 Dictionary of National Biography, xxxiv. 230. 
that Parliament which the army, we are told, had reduced to 'impotence' (p. I32) and of which the name had been usurped by a minority resting on the sword. $\mathrm{He}$ was a traitor to nothing but the usurpation of the army.

But the contrast suggests yet another thought. It will occur to most right-minded people that it would, to say the least of it, have been more decent if Fairfax, who had sent the knights to their death, had taken a less prominent part in doing what they had attempted to do-in restoring the king to his own again by force of arms-or, at any rate, had been less effusive in his welcome of 'the second Charles.' 1

No denunciations of 'hireling slanderers' (p. 399) or of 'the vile crew' of critics (p. 328) can obscure these grave facts. Intolerable though it may appear to Mr. Markham, in his blind adoration of this 'spotless knight' (pp. 399, 40I, \&c.), the thoughtful and impartial student of those times is more than justified on the above grounds in withholding from the shuffling and shifty Fairfax that respect which he gladly pays to the dauntless martyrs of a cause-to the republicanism of a Corbet or a Vane, as to the loyalty of a Lucas or a Lisle.

1 Only some weeks before his actual rising in arms, and when he had been resolved for some time to act ' with a view to the restoration' (Life, p. 375), he gave an illustration of his 'perfect consistency and good faith' (Ib. p. 385), by swearing in officers to be 'true faithfull and constant to this Commonwealth without a single person, Kingshipp, or House of Peers'; while on the very day when, according to Mr. Markham, he ' secured the restoration of the monarchy' (p. 382), this 'heroic' man wrote to the Rump: 'We desire you to be assured that what hath been done was only in order to your service.' 